\title{
Exploring Routes to Persuasive Online Advertising
}

\author{
Wen-Chin Tsao ${ }^{1}$ \\ ${ }^{1}$ Department of Business Administration, National Chin-Yi University of Technology, Taiwan, Republic of China \\ Correspondence: Wen-Chin Tsao, Department of Business Administration, National Chin-Yi University of \\ Technology, No. 57, Sec. 2, Zhongshan Rd., Taiping Dist., Taichung 41170, Taiwan, Republic of China. E-mail: \\ tsao@ncut.edu.tw
}

Received: September 25, 2014

Accepted: November 3, 2014

Online Published: November 22, 2014

doi:10.5539/ijbm.v9n12p35

URL: http://dx.doi.org/10.5539/ijbm.v9n12p35

\begin{abstract}
Studies show that the Internet is gaining status as a mainstream medium for delivering advertisements and that online advertising may surpass advertising in traditional media. This study proposes a model for evaluating the effects of various elements of Internet advertisements on purchase intention and outlines a potential route by which persuasive messages might travel. A structural equation model is developed to test the causal effect between those constructs. The multiple-group analysis is applied to investigate the moderating effect of Internet usage.

The empirical results show that (1) purchase intention is influenced indirectly by peripheral cues via the mediation of hedonic value, (2) purchase intention is influenced indirectly by central cues via the mediation of utilitarian value and search intention, (3) Internet usage plays a partial moderating role in persuasive communication, and (4) utilitarian value plays a critical meditating role by converting rational ad stimuli into purchase acts after the persuasive communication effected by online advertisements. This study clarified the process of consumer perception and interpretation towards online advertisement information, proposing two pathways for persuasion. Furthermore, we confirmed that in the event that more central cures are released in online advertisements, the consumers will enhance a greater utilitarian value to the message. This further induces greater search intention and purchase intention, the finding of which is the contribution of this study.
\end{abstract}

Keywords: elaboration likelihood model, hedonic value, utilitarian value, persuasive message, internet usage, central route, banner advertisement

\section{Introduction}

With the Internet and electronic commerce becoming widely used, online advertisement is attracting more attention as an important source of information, and is becoming more and more lucrative for business worldwide (Nakamura \& Abe, 2005; Sonal \& Preeta, 2005). Media reports indicate that Internet advertisement expenditure in the United States as a percentage of total advertisement expenditure showed a steep upward trend between 2006 and 2009. In 2009, of all advertisement expenditure, 12.5 percent was directed towards Internet advertisements. This amount was second only to the amount used for newspaper ads, which accounted for 14.6 percent (eMarketer, 2009). The study showed that Internet advertising hit $\$ 99$ billion in 2012, representing a 16.2 percent increase over the previous year and accounting for 19.5 percent of all global measured online advertising expenditures (Dohnert, 2013). The study also predicted that in 2013 online advertising spending will reach $\$ 113.5$ billion globally, 14.6 percent more than 2012. The figure represents more than 21 percent of all measured advertising investment (Dohnert, 2013).It appears that the Internet is gaining status as a mainstream advertising medium and that online advertisement may surpass traditional media (Blundo, Cimato \& De, 2005). This prompts the author to explore the impact of Internet message content on persuasive communication.

Banner advertisement on the Internet is a new form of advertisement which, by allowing the consumers to click on the banner of their choice and obtain information. Unlike conventional advertisements, Internet advertisements can interact with consumers, and consumers can choose the advertisements they want to see by clicking on them rather than be forced to receive advertisement contents. With the wide use of Internet and electronic commerce, Internet advertisements are becoming increasingly important channels by which consumers receive information and corporations gain income (Nakamura \& Abe, 2005). Unlike traditional marketing channel, the web offers rich man-machine interactivity, rendering marketing channels and advertisements more efficient. As the Internet 
becomes more important in electronic commerce, more advertisers are hoping to use this new means of advertising to fully communicate with consumers (Wang, Beatty, \& Mothersbaugh, 2009). Corporations are also beginning to understand the power of the Internet and becoming aware that Internet advertisements are simple and effective tools for promotions and communication. In fact, the Internet plays the role of a new powerful communication channel used to reach a large number of potential customers and to influence their purchase behavior (Blundo et al., 2005). This shows that unlike conventional advertising methods, Internet advertisements provide consumers with the initiative in addition to being more convenient and interactive. Having no boundaries, the Internet enables Internet advertising to reach markets that conventional advertising cannot, and as a result, Internet advertising can develop more potential consumers.

For decades, in their study of attitude formation, researchers have paid close attention to the task of validating the paradigm of C-A-B: cognition, affect, and behavior (Holbrook, 1978). According the CAB attitude model, consumers initially form beliefs about a certain object by accumulating knowledge with regard to key attributes of the object. Once these beliefs have been formed, feelings (or affective responses) will follow. The affective responses eventually shape the consumers' behavioral intention (Solomon, Bamossy, \& Askegaard, 2002). Although the $\mathrm{CAB}$ model is suitable for explaining the attitudes of individual regarding high-involvement products, it is not as effective in explaining online purchases, especially purchases of low-involvement or highly-experimental products (Chen \& Lee, 2008). In addition to the CAB model, the elaboration likelihood mode (ELM) is one of the important theories that many scholars have referred to in their study of the formation of and changes in the attitudes of individuals. According to the ELM theory, high-involvement consumers tend to follow the central route of information processing on which more cognitive resources are allocated to judge and elaborate message arguments. Low-involvement consumers, however, often pay more attention to peripheral attributes, such as the color, the transaction context, or the background music, when forming attitudes toward an ad (Wang et al., 2009). Some researchers argue that the ELM is better than CAB in explaining how online consumers are convinced by persuasive messages and how their attitudes are formed (Salo \& Karjaluoto, 2007; Yoon, 2002). Therefore, this study will incorporate the theories employed by the ELM.

Using the paradigms of stimulus-organism-response(S-O-R) (Fiore \& Kim, 2007) to design for this paper and applying the theory of ELM to explore the process of persuasive communication, this study intends to (1) explore how two types of message elements that Internet advertisement spreads (the type of central cues and the type of peripheral cues) affect consumers' utilitarian and hedonic values, (2) explore how perceived value of message elements affect the intention of prospective consumers to further search on the advertised product or to purchase, and (3) outline a potential route by which persuasive messages of online advertisement might travel via online advertisement. This paper concludes with a discussion of managerial implications and directions for future research.

\section{Research Hypotheses and Conceptual Framework}

\subsection{Central and Peripheral Routes to Persuasion}

Persuasive communication aims to explain how consumers process and elaborate on persuasive messages to form their attitudes, positive or negative, toward an object or entity. The ELM specifically considers two different routes by which individuals process persuasive communication (Petty \& Cacioppo, 1986). When a central route is used, the audience processes the advertisement message by cognitively elaborating on it. In other words, consumers will focus on core elements of the object of the advertisement, which are called central cues or message content. Attitudes formed and changed via this route are considered to be relatively enduring, resistant to change, and more predictive of behavior (Petty \& Cacioppo, 1984; Morris, Chong, \& Singh, 2005; Keng, Liao, \& Yang, 2012).

Via the peripheral route, though, the audience - which possesses a low level of motivation and evaluation ability - will not deeply consider the core message of the communication but will instead form an attitude based on contextual elements of the message, including attractive expert opinions, brand reputation, the identity of the endorser, the product's country of origin, music, atmosphere, and other such peripheral cues (Petty \& Cacioppo, 1984). People taking this route to process persuasive messages have less cognition of the object being touted, and their attitude toward that object is not formed without deep thought and consideration. Consequently, such attitude tends to be relatively temporary, susceptible, and unpredictive of behavior (Petty \& Cacioppo, 1984; Morris et al., 2005).

\subsection{Utilitarian and Hedonic Value}

Utilitarian value is regarded as indicating overall functional benefits and costs (Overby \& Lee, 2006). It corresponds to the traditional notion of instrumental or utilitarian performance, in which products are seen as performing useful functions. In contrast, hedonic value can be thought of as an overall assessment of experiential 
benefits and costs; products are valued for their intrinsically pleasing properties, which provide enjoyment during the experiential process (Bridges \& Florsheim, 2008; Voss, Spangenberg, \& Grohmann, 2003).

This research applies the concept of utilitarian and hedonic value to the analysis of online advertising. If consumers feel that the message appeals to their sense of practicality and that the object being advertised is going to help them accomplish some objective, the advertising message is said to possess utilitarian value. If, however, consumers feel that the message appeals to their desire for pleasure or suggests that they will experience satisfaction after consuming the advertised object, then the advertising message is said to possess hedonic value (Batra \& Ahtola, 1990; Voss et al., 2003).

Consumers are inclined to rely heavily on peripheral cues such as brand awareness, non-product-related attributes, and experiential and perceived symbolic benefits (e.g., user imagery, endorser reputation, etc.) to judge the hedonic value of a product or persuasive message rather than taking concrete attributes into account (Petty \& Cacioppo, 1986; Johar \& Sirgy, 1991). When advertisement messages release more peripheral cues, including visual and aural stimulations such as web page color, layout, a spokesperson, music, or aesthetics, they allow message receivers to be more relaxed and enter another realm of life that brings them more happiness (Lehdonvirta, 2009). In addition, Chen and Lee (2008) confirm the existence of a positive correlation between a website's peripheral cues and hedonic value. On this basis, this hypothesis is proposed:

H1. When online consumers perceive an Internet-advertised persuasive message as having more peripheral cues, the consumers will assign a greater hedonic value to the message.

Johar and Sirgy (1991) suggest that an advertisement that relies primarily on the utilitarian appeal of the advertised object tends to help make its audience more knowledgeable about the object's function and value, encouraging the consumers to process the advertisement via the central route, thus making the advertisement more persuasive. Fiore and Kim (2007) argue that the more consumers perceive store layout as allowing for the efficient acquisition of goods, the better they will perceive the utilitarian value of shopping. Likewise, the more consumers perceive central cues from online advertisement, by cognitively elaborating on that message, i.e., issue-relevant thinking, the more likely that they would form their opinion on the practicality of that advertised message (Petty \& Cacioppo, 1986; Johar \& Sirgy, 1991). Thus,

H2. The more central cues that online consumers perceive from a persuasive message in an online advertisement, the more utilitarian value they perceive from that advertisement.

Babin et al. (1994) point out that utilitarian and hedonic values are not merely alternatives to one another but also actually interact. Hansen (2005) also posits that an overall assessment of utility based on perceptions will lead to a greater emotional reaction. Fiore and Kim (2007) argue that when consumers feel that they can more efficiently acquire goods because the desired items are easy to locate, they will also feel that they have time for more leisurely browsing and, therefore, feel pleasure. This argument also affirms that utilitarian value leads to awareness of hedonic value. Thus,

H3. The amount of utilitarian value that online consumers associate with an Internet advertisement will be correlated with the amount of hedonic value that they perceive from the same advertisement.

\subsection{Search Intention}

Studies have shown that background music stimulates consumers and sways consumption behavior and that fast-tempo music makes people happier, more cheerful and more excited (Morris \& Boone, 1998). Research has shown that hedonically motivated consumers will browse websites and conduct searches before making a purchase. In providing services and answering customers' questions, web pages can also provide sensory stimulation and encourage excitement. This and the ability of web sites to offer a positive visit experience for consumers are both factors that actively affect the search intentions of consumers (Wolfinbarger \& Gilly, 2001). When online purchasers perceive more pleasure from an Internet advertisement, they may be more willing to search or browse in order to find and price compare the product or service that the advertisement was touting. Therefore, the following hypothesis emerges:

H4. When an online consumer perceives an online advertising message as having more hedonic value, their intention to conduct further web searches will increase.

Mathwick et al. (2001) suggest that consumer purchasing behavior (and, hence, online purchasing behavior) will be influenced by external values such as utility. Thus, it will be necessary to further analyze utilitarian value to identify the hidden value embedded therein and to package various aspects of utilitarian value to stimulate purchasing. These aspects of value might include the notion of "getting more than your money's worth" (Zeithaml, 1988), the ease with which the consumer can make the purchasing decision, and the ability to save time (Teo, 
2001). An advertisement that promotes utility may could help online consumers decrease search time, attain price comparison information, and therefore elevate their interest in conducting further searching on the web. Hence, it is hypothesized that:

H5. When online consumers perceive an Internet advertisement as having more utilitarian value, their intention to conduct web searches increases.

\subsection{Purchase Intention}

Purchase intention refers to the probability that a consumer will make a purchase. Greater purchase intention implies a higher probability of purchase. Purchase intention is often used as a metric in predicting purchasing behavior (Morwitz \& Schmittlein, 1992). Goal-directed searches and exploratory searches can influence consumers' purchase intentions (Moe, 2003). Therefore, promotion activity on web sites, the services provided by online stores, and web page design all influence the intention and willingness of consumers to visit a web site and conduct a search - and, hence, increase purchase intention. Thus, this study posits the following:

H6. When online consumers' intention to search for the object of an online advertisement is elevated, their purchase intention increases.

\subsection{Moderating Effect of Internet Usage}

Assael (2005) points out that a comparison between heavy Internet users and all Internet users as a whole reveals differences in their demographics and lifestyle profiles. These demographics are most markedly different in age and income. As for lifestyle differences, heavy internet users tend to have liberal social views with an optimistic view of the future and were self-improvisers. Those people apparently feel that they are time-deprived which made them a multitasking group that tend to do more and seek to do more then they currently had on their plate.

Kotler and Keller (2008) contend that a consumer's buying behavior is influenced by personal factors such as age, income, behavior, lifestyle, and values. Furthermore, Fiore and Kim (2007) suggest that personal factors are important moderators in the S-O-R framework. Thus,

H7. Internet usage plays a significant moderating role in those causal paths within the conceptual model.

On the basis of the aforementioned literature review and hypotheses, the conceptual model for this study is derived as shown in Figure 1.

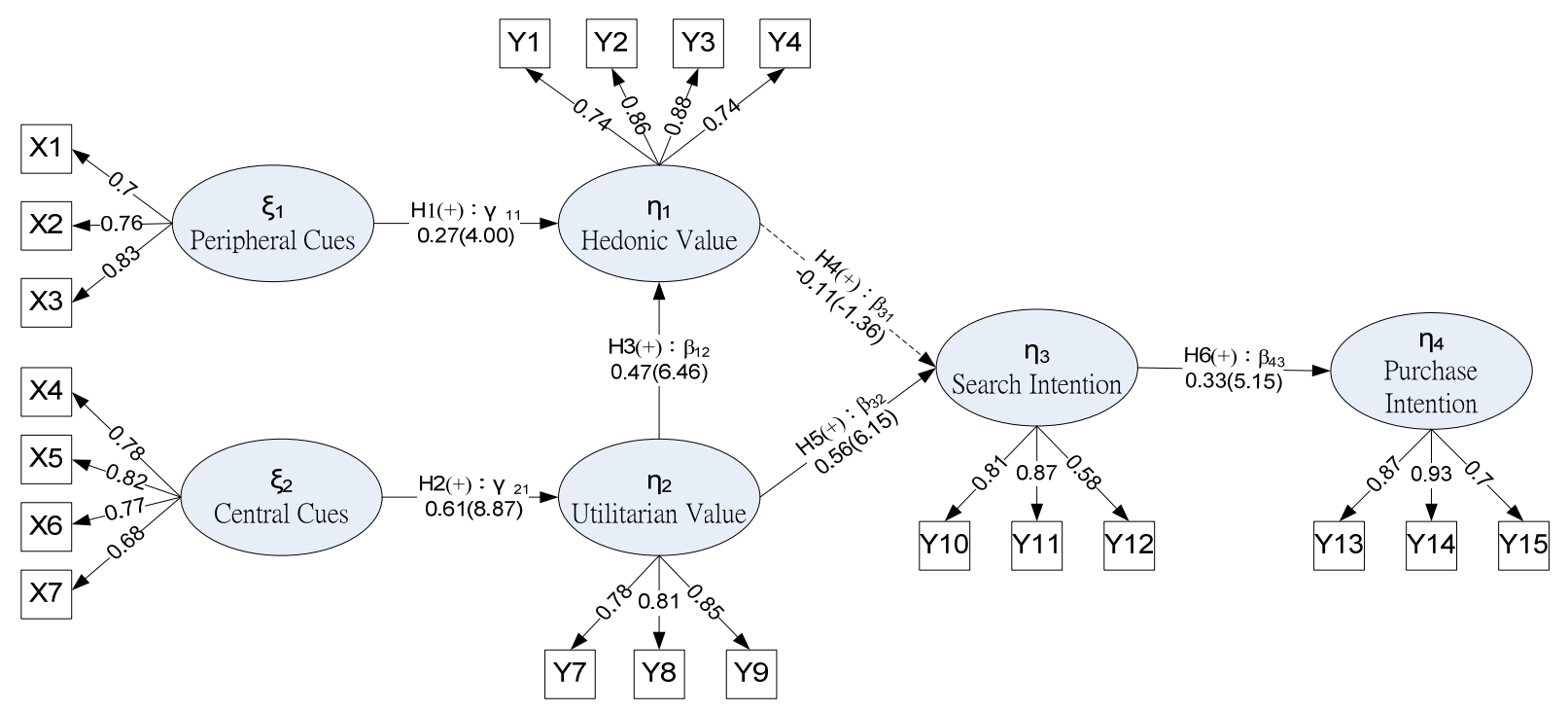

Note: Continuous lines are supported paths and dotted lines, unsupported.

Figure 1. The results of the hypothesized model $\left(\mathrm{M}_{\mathrm{H}}\right)$.

\section{Methods}

\subsection{Development of Measures}

Based on several research papers on the ELM (Petty, Cacioppo, \& Goldman, 1981; Petty \& Cacioppo, 1984; 
Eckert \& Goldsby, 1997; Morris et al., 2005), the author develops 10 questions to measure two constructs: central cues and peripheral cues. Central cues were measured by five items on whether the advertisement contained easy-to-obtain product information, details on the functions and features of the product, quick web page links, and promotions and whether the product could enhance the quality of life. Five items (positive emotion, good reputation, geniality, energy, and celebrity effectiveness) were used to measure the peripheral cues. Utilitarian value and hedonic value are measured using ten seven-point semantic-differential items adopted from Voss et al. (2003). Hence, hedonic value was measure by five items (not fun/ fun, dull/exciting, not delightful/delightful, not thrilling/thrilling, not enjoyable/enjoyable). Utilitarian value was gauged with the following five items: ineffective/effective, unhelpful/helpful, not functional/function, impractical/practical, unnecessary/necessary (Voss et al., 2003). The four questions about search intentions are based on Chen and He (2003). Purchase intention is defined as the likelihood that a buyer will purchase a product. For this study, the three-item metrics used based on Dodds et al.'s (1991) study are probability, willingness, and likelihood. With the exception of utilitarian and hedonic value, all constructs were measured using the seven-point Likert scale ranging from 1 (strongly disagree/very low) to 7 (strongly agree/very high).

\subsection{Research Design and Data Collection}

For this research's advertisement stimuli, the author chose 16 real Internet advertisements focused on some of the most popular products or services according to a poll on www.pollster.com.tw, items such as clothing, shoes, handbags, cosmetics, weight loss management items, health products, and computer accessories. Research assistants downloaded the 16 advertisements onto their computers and set out to recruit subjects in four steps.

First, they secured the consent of the subjects and made appointments for the administration of the test. Second, they explained in detail what the subjects had to do and each subject spent at least ten minutes to select three advertisements from the sixteen available. Third, the subjects each selected one of the three that they had picked, and watched carefully just this one advertisement and then filled out a questionnaire. Finally, the questionnaires were collected for analysis.

\subsection{Sample Profile}

The subjects for this study were all individuals with experience using the Internet in Taiwan. However, the unavailability of a list of shoppers in the population as the sample frame forced this research to take a convenience sampling approach. Because all subjects were required to view the advertisement online at our location, the sample population was limited to where we could reasonably have online computers available for the purpose.

In all, we recruited 340 people for the test, primarily undergraduate students at the business school at National Chin-Yi University of Technology, although a few individuals were also patients or medical care providers at Taichung Cheng Ching Hospital. Of the questionnaires completed, 28 were invalid, leaving 312 usable questionnaires. Hair et al. (1998) suggested that the sample size for an SEM analysis be at least five times (or better, ten times) as large as the estimated parameters being analyzed in the model. With 312 valid samples, this study satisfied Hair's suggestion. The sample profile is presented in Table 1.

Table 1. Sample profile

\begin{tabular}{llllll}
\hline $\mathrm{N}=312$ & Frequency & $\%$ & & Frequency & $\%$ \\
\hline Gender & & & Education & & \\
Female & 252 & 80.77 & high school or less & 4 & 1.28 \\
Male & 60 & 19.23 & 2-/4-year college & 285 & 91.35 \\
\cline { 1 - 1 } Age & & & Master/ Doctorate & 23 & 7.37 \\
Under 20 & 176 & 56.41 & Type of consumer product purchased & & \\
$21-25$ & 103 & 33.01 & Male/Female clothingand accessories & 200 & 78.13 \\
$26-30$ & 17 & 5.44 & Cosmetics & 115 & 44.92 \\
$31-35$ & 11 & 3.53 & Books and magazines & 94 & 36.72 \\
$36-40$ & 1 & 0.32 & Communication, electronics, computers & 70 & 27.34 \\
Over 41 & 4 & 1.29 & Watches, jewelry & 46 & 17.97 \\
& & & Food and specialty food & 35 & 13.67 \\
& & & Stationery & 28 & 10.94 \\
& & & Others & 80 & 31.25 \\
\hline
\end{tabular}

Note. ${ }^{\text {a }}$ This section of the table used multiple choices. Of the 312 subjects in the population, only 256 actually bought things on the Internet. Therefore for purposes of calculating the frequency \%, 256 was used as the denominator. For example, 200/256=78.13\%. 


\section{Rresults}

\subsection{Reliability and Validity}

Bagozzi and Yi (1988) suggest that the item-total correlation for each question must be 0.5 or higher. Based on this criterion, 7 of the 27 questions from the six constructs were disqualified, leaving 20 questions included in the final questionnaire (see Table 2).

Table 2. Scale items and measurement properties of six constructs

\begin{tabular}{|c|c|c|c|}
\hline Construct/item & $\begin{array}{l}\text { Standardized } \\
\text { Loadings }\end{array}$ & $\begin{array}{l}t- \\
\text { value }\end{array}$ & $\alpha^{\mathrm{b}}$ \\
\hline \multicolumn{4}{|l|}{ Peripheral Cues $\left(\rho_{\mathrm{c}}=0.80 ; \text { AVE }=0.58\right)^{\mathrm{a}}$} \\
\hline $\mathrm{X} 1$ : Firm has a good reputation & 0.70 & $\ldots$ & \multirow{3}{*}{0.80} \\
\hline $\mathrm{X} 2$ : Advertisement conveys geniality & 0.75 & 11.61 & \\
\hline $\mathrm{X} 3$ : This is an energetic & 0.82 & 12.29 & \\
\hline \multicolumn{4}{|l|}{ Central Cues $\left(\rho_{c}=0.85 ; \text { AVE }=0.59\right)^{\mathrm{a}}$} \\
\hline $\mathrm{X} 4$ : Advertisement contains information that helps me search for related product information & 0.78 & $\ldots$ & \multirow{4}{*}{0.85} \\
\hline X5 : Advertisement provides detailed product functionality and features. & 0.82 & 14.80 & \\
\hline X6 : Advertisement provides links that help me to quickly connect to other sites & 0.78 & 14.02 & \\
\hline X7 : Advertisement provides good promotion incentives. & 0.68 & 11.90 & \\
\hline \multicolumn{4}{|l|}{ Hedonic Value $\left(\rho_{\mathrm{c}}=0.90 ; \text { AVE }=0.69\right)^{\mathrm{a}}$} \\
\hline X8 : dull $\longrightarrow$ exciting & 0.73 & $\ldots$ & \multirow{4}{*}{0.90} \\
\hline X9 : Not delightful $\longrightarrow$ delightful & 0.85 & 15.13 & \\
\hline X10 : Not thrilling $\longleftrightarrow$ thrilling & 0.88 & 15.63 & \\
\hline X11 : Not enjoyable $\longrightarrow$ enjoyable & 0.83 & 14.73 & \\
\hline \multicolumn{4}{|l|}{ Utilitarian Value $\left(\rho_{\mathrm{c}}=0.83 ; \mathrm{AVE}=0.61\right)^{\mathrm{a}}$} \\
\hline X12 : ineffective $\longleftarrow$ effective & 0.78 & $\ldots$ & \multirow{3}{*}{0.83} \\
\hline $\mathrm{X} 13:$ Not functional $\longleftrightarrow$ functional & 0.81 & 13.71 & \\
\hline $\mathrm{X} 14:$ impractical $\longleftrightarrow$ practical & 0.76 & 13.07 & \\
\hline \multicolumn{4}{|l|}{ Search Intention $\left(\rho_{\mathrm{c}}=0.80 ; \text { AVE }=0.58\right)^{\mathrm{a}}$} \\
\hline $\begin{array}{l}\text { X15 : After viewing the advertisement, I will serf the Net to browse product information provided } \\
\text { in the ad. }\end{array}$ & 0.81 & $\cdots$ & \multirow{4}{*}{0.79} \\
\hline X16 : I would search for more information through search engines before buying on the Internet & 0.87 & 13.05 & \\
\hline X17 : I will not buy directly from an online store without serious online comparison shopping. & 0.58 & 9.99 & \\
\hline \multicolumn{3}{|l|}{ Purchase Intention $\left(\rho_{\mathrm{c}}=0.88 ; \text { AVE }=0.70\right)^{\mathrm{a}}$} & \\
\hline $\mathrm{X} 18$ : My willingness to buy the advertised product is: (very low to very high) & 0.88 & $\ldots$ & \multirow{3}{*}{0.87} \\
\hline $\begin{array}{l}\text { X19 : The probability that I will consider buying the product advertised online is:( very low to } \\
\text { very high) }\end{array}$ & 0.91 & 19.25 & \\
\hline $\mathrm{X} 20$ : The likelihood of online purchasing of the advertised product is: (very low to very high) & 0.71 & 14.40 & \\
\hline GoodnessofFit $: \chi_{(321)}^{2}=272.37 ; \chi^{2} /$ d.f. $=1.76 ;$ GFI $=0.92 ;$ AGFI $=0.90 ;$ RMSEA $=0.06$ & & & \\
\hline
\end{tabular}

Note. ${ }^{\text {a }}$ For each construct, scale composite reliability $\left(\rho_{\mathrm{c}}\right)$ and average variance extracted (AVE) are provided. These are calculated using the formulae provided by Fornell and Larcker (1981) and Baggozzi and Yi (1988).

${ }^{\mathrm{b}}$ Cronbach's $\alpha(\alpha)$ means internal consistency.

Then CFA was used to verify the unidimensionality of each construct (Anderson \& Gerbing, 1988). As illustrated in Table 2, all Cronbach's alpha estimates were greater than or equal to 0.7 ; indeed, they ranged from 0.79 to 0.90 . The figures for composite reliability $(\rho c)$ were all greater than 0.6 , indicating that each construct met the requirement for internal consistency (Fornell, 1992; Nunnally \& Bernstein, 1994).

As shown in Table 2, the measurement properties of the six constructs indicated that the factor loadings (lambdas) were greater than 0.5 and significant (the t-values for the factor loadings ranged from 9.99 to 19.25 , exceeding 2), which satisfied the criteria for convergent validity (Hair, Anderson, Tatham, \& Black, 1998; Simonin, 1999).

Discriminant validity is assured when the shared variance among any two constructs (i.e., the square of their intercorrelation) is less than the AVE of each construct (Fornell \& Larcker, 1981). As shown in Table 3, the AVE of the underlying construct was higher than their shared variance with other constructs. Thus, the six constructs exhibited discriminant validity. 
The chi-square test was significant $\left(\chi_{(312)}^{2}=272.37, \mathrm{p}<0.001 ; \chi^{2} / \mathrm{df}=1.76\right)$, which has not been surprising, given the large sample size $(n=312)$ (Benlter, 1990). Other fit indices are also shown in Tables 2 . These indices indicate a reasonable level of fitness in favor of this model (Bagozzi \& Yi, 1988).

Table 3. Fornell/Larcker test for six constructs

\begin{tabular}{lllllll}
\hline Construct & F1 & F2 & F3 & F4 & F5 & F6 \\
\hline F1 & 0.59 & & & & & \\
F2 & 0.58 & 0.58 & & & & \\
F3 & 0.20 & 0.29 & 0.69 & & & \\
F4 & 0.33 & 0.29 & 0.38 & 0.61 & & \\
F5 & 0.20 & 0.12 & 0.04 & 0.20 & 0.59 & \\
F6 & 0.20 & 0.18 & 0.19 & 0.28 & 0.01 & 0.70 \\
\hline
\end{tabular}

Note. F1, Central cues; F2, Peripheral cues; F3, Hedonic value; F4, Utilitarian value; F5, Search intention; F6, Purchase intention; Average variance extracted on diagonal; the square of their intercorrelation below the diagonal.

\subsection{The Fitness of the Structural Model and Hypotheses Tests}

The structural equation model (SEM) was used to estimate the parameters of the structural model shown in Figure 1 , and the completely standardized solutions computed by the Amos 17.0 maximum-likelihood method are reported in Table 4.

Table 4. Structural parameter estimates and goodness-of-fit indices

\begin{tabular}{lllll}
\hline Hypotheses & Paths & Estimate $^{\mathrm{a}}$ & $t$-value & Result \\
\hline H1 & Peripheral Cues $\rightarrow$ Hedonic Value & $\gamma_{11} 0.27$ & $4.00^{*}$ & Supported \\
H2 & Central Cues $\rightarrow$ Utilitarian Value & $\gamma_{21} 0.61$ & $8.87 *$ & Supported \\
H3 & Utilitarian Value $\rightarrow$ Hedonic value & $\beta_{12} 0.47$ & $6.46^{*}$ & Supported \\
H4 & Hedonic Value $\rightarrow$ Search Intention & $\beta_{31}-0.11$ & -1.36 & Unsupported \\
H5 & Utilitarian Value $\rightarrow$ Search Intention & $\beta_{32} 0.56$ & $6.15^{*}$ & Supported \\
H6 & Search Intention $\rightarrow$ Purchase Intention & $\beta_{43} 0.33$ & $5.15^{*}$ & Supported \\
\hline Goodness of Fit $: \chi^{2}{ }_{(312)}=364.96 ;$ d.f. $=163 ; \chi^{2} / \mathrm{df}=2.24 ;$ GFI $=0.90 ;$ AGFI=0.87; RMSEA $=0.06$ \\
\hline Note. ${ }^{\text {a }}$ Standardized estimate; $*$ Significant at $p<0.05(\mathrm{t}>1.96$ or $\mathrm{t}<1.96)$.
\end{tabular}

As shown in Table 4, all fit measures in the structural model had fit the data reasonably well $\left(\chi_{(312)}^{2}=364.96\right.$; $\mathrm{df}=163 ; \chi^{2} / \mathrm{df}=2.24 ; \mathrm{GFI}=0.90 ; \mathrm{AGFI}=0.87 ; \mathrm{CFI}=0.94$; RMSEA=0.06). With the exception of AGFI (which was slightly low) and RMSEA (which was slightly high), all other indices met the criteria (Bagozzi \& Yi, 1988; Jöreskog \& Sörbom, 1992; Hair, Black, Babin, Anderson, \& Tatham, 2006). Scholars generally suggest that an AGFI of more than 0.9 is necessary before a model can be judged as having an ideal level of fitness (Hu \& Bentler, 1999). However, other scholars recommend that the threshold be relaxed (Baumgartner \& Homburg, 1996). Accordingly, the AGFI of this research model is acceptable. The RMSEA of this model, although slightly higher than 0.05 , still falls in the acceptable range of 0.05 to 0.08 (Browne \& Cudeck, 1992).

The standardized estimates for the various paths and their associated $t$-values are provided in Table 4 and Figure 1. As expected, the causal path from peripheral cues to hedonic value is positive and significant $\left(\gamma_{11}=0.27, t=4.00\right)$. Thus, $\mathrm{H} 1$ is supported. As is evident in Table 4, central cues significantly and positively affects utilitarian value $\left(\gamma_{21}=0.61, \mathrm{t}=8.87\right)$, supporting $\mathrm{H} 2$. In addition, utilitarian value has a significant and positive effect on hedonic value $\left(\beta_{12}=0.47, t=6.46\right)$, supporting $H 3$. Unexpectedly, hedonic value is not positively and significantly related to search intention $\left(\beta_{31}=-0.11, \mathrm{t}=-1.36\right)$, and therefore $\mathrm{H} 4$ is not accepted. While utilitarian value has a significant and positive relationship with search intention $\left(\beta_{32}=0.56, \mathrm{t}=6.15\right)$, validating $\mathrm{H} 5$. As hypothesized, search intention is positively and significantly related to purchase intention $\left(\beta_{43}=0.33, \mathrm{t}=5.15\right)$. Thus, the result provides support for H6. This confirms that the greater the degree of purchase intention that online shoppers have, the greater the level of purchase intention to shop in e-stores. 


\subsection{Confirming the Optimal Model}

A further analysis of the results indicates that the path coefficient for hedonic value and search intention is "negative" $\left(\beta_{31}=-0.11, t=-1.36\right)$, unlike in the previous literature. Therefore, this research attempted to establish an alternative model to compare with the original model and to choose the ultimate, best model. Consumers who select the peripheral route to persuasion tend to process persuasive messages using low levels of thought and analysis, which encourages affective reactions to messages (Petty et al., 1981). Furthermore, this type of consumers tends to follow the low-involvement hierarchy of CBA theory to form their attitude toward the advertised object (Solomon et al., 2002). Therefore, this research established alternative model $1\left(\mathrm{M}_{\mathrm{A} 1}\right.$, see Figure 2 ), in which search intention did not play a full mediating role in the relationship between hedonic value and purchase intention.

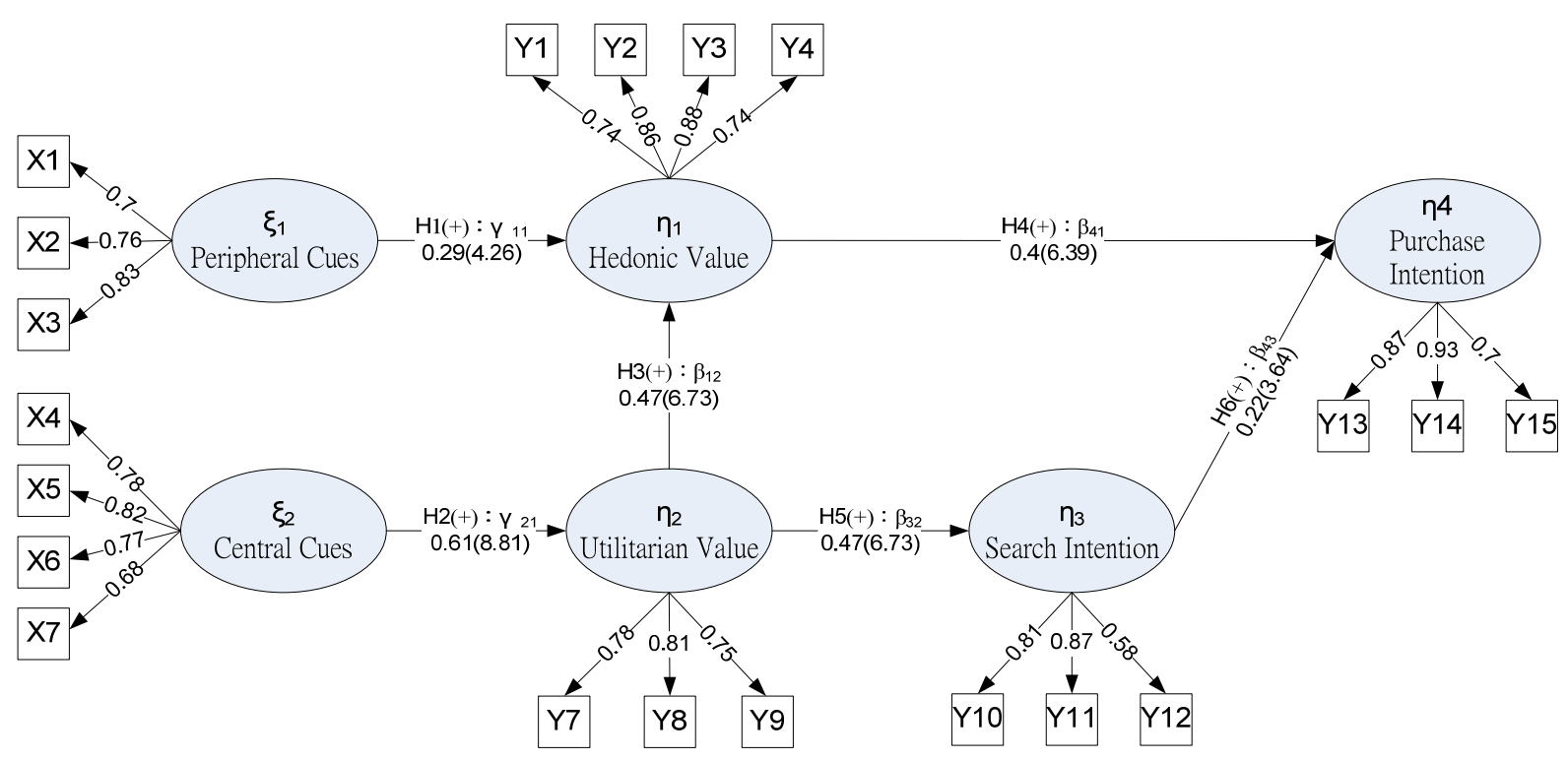

Note: Continuous lines are supported paths and dotted lines, unsupported.

Figure 2. The results of an alterative model $1\left(\mathrm{M}_{\mathrm{A} 1}\right)$.

To increase confidence in the model specification, we tested the hypothesized model $\left(\mathrm{M}_{\mathrm{H}}\right)$ against alternative model specifications $\left(\mathrm{M}_{\mathrm{A1}}\right)$ (Anderson \& Gerbing, 1988). Anderson and Gerbing (1988) recommend that this procedure and suggest the use of a chi-square difference (CDT) to test the null hypothesis: $\mathrm{M}_{\mathrm{H}}-\mathrm{M}_{\mathrm{A}}=0$. Compared with a less parsimonious $\mathrm{M}_{\mathrm{A}}$, a non CDT would lead to the acceptance of the more parsimonious $\mathrm{M}_{\mathrm{H}}$.

Table 5 lists the statistics for the sequential chi-squire difference tests (CDTs) and the comparison of model fit. There was no need to use a CDT because the degree of freedom was the same for the two models. Instead, we directly compared the fitness indices for these two models. In comparing the fitness of the hypothesized model $\left(\mathrm{M}_{\mathrm{H}}\right)$ and the alternative model $1\left(\mathrm{M}_{\mathrm{Al}}\right)$, we worked from the assumption that the smaller a model's $\chi^{2} \cdot \chi^{2} / \mathrm{df}$ and RMSEA are, the better fit the model has. We also assumed that the larger a model's GFI, AGFI, and CFI are, the better the fit is. The significantly better fit of MA1 led us to prefer alternative model 1 to the hypothesized model, $\mathrm{MH}$. In other words, in the relationship between hedonic value and purchase intention, search intention was better omitted as a mediator.

Table 5. Sequential chi-square tests

\begin{tabular}{lllllllll}
\hline Model & d.f. & $\chi^{2}$ & $\Delta \chi^{2}$ & $\chi^{2} /$ d.f. & GFI & AGFI & CFI & RMSEA \\
\hline $\mathrm{M}_{\mathrm{H}}$ & 163 & 364.96 & --- & 2.24 & 0.90 & 0.87 & 0.94 & 0.06 \\
$\mathrm{M}_{\mathrm{A} 1}$ & 163 & 320.62 & --- & 1.97 & 0.91 & 0.88 & 0.95 & 0.06 \\
$\mathrm{M}_{\mathrm{A} 2}$ & 162 & 317.59 & 3.03 (ns) & 1.96 & 0.91 & 0.88 & 0.95 & 0.06 \\
\hline
\end{tabular}

Note. $\mathrm{M}_{\mathrm{H}}$, Hypothesized model; $\mathrm{M}_{\mathrm{A} 1}$, Alternative model $1 ; \mathrm{M}_{\mathrm{A} 2}$, Alternative model 2; $\chi^{2}$ difference test is tested by the $\Delta \chi^{2}>3.84, p<0.05$. 
Then we examined whether there was any partial mediating effect at play by creating an alternative model $2\left(\mathrm{M}_{\mathrm{A} 2}\right.$, see Figure 3) to compare with $\mathrm{M}_{\mathrm{Al}}$. We also compared alterative model 1 with alternative model 2, in which search intention did play a partial mediating role in the relationship between hedonic value and purchase intention. According to the CDT (Anderson \& Gerbing 1988), the less parsimonious model $\left(\mathrm{M}_{\mathrm{A} 2}\right)$ was not significantly better than alternative model $1\left(\mathrm{M}_{\mathrm{A} 1}\right)$ in that the value of $\Delta \chi^{2}$ was not greater than 3.84. This result led us to conclude that $\mathrm{M}_{\mathrm{Al}}$ was the better model for this study.

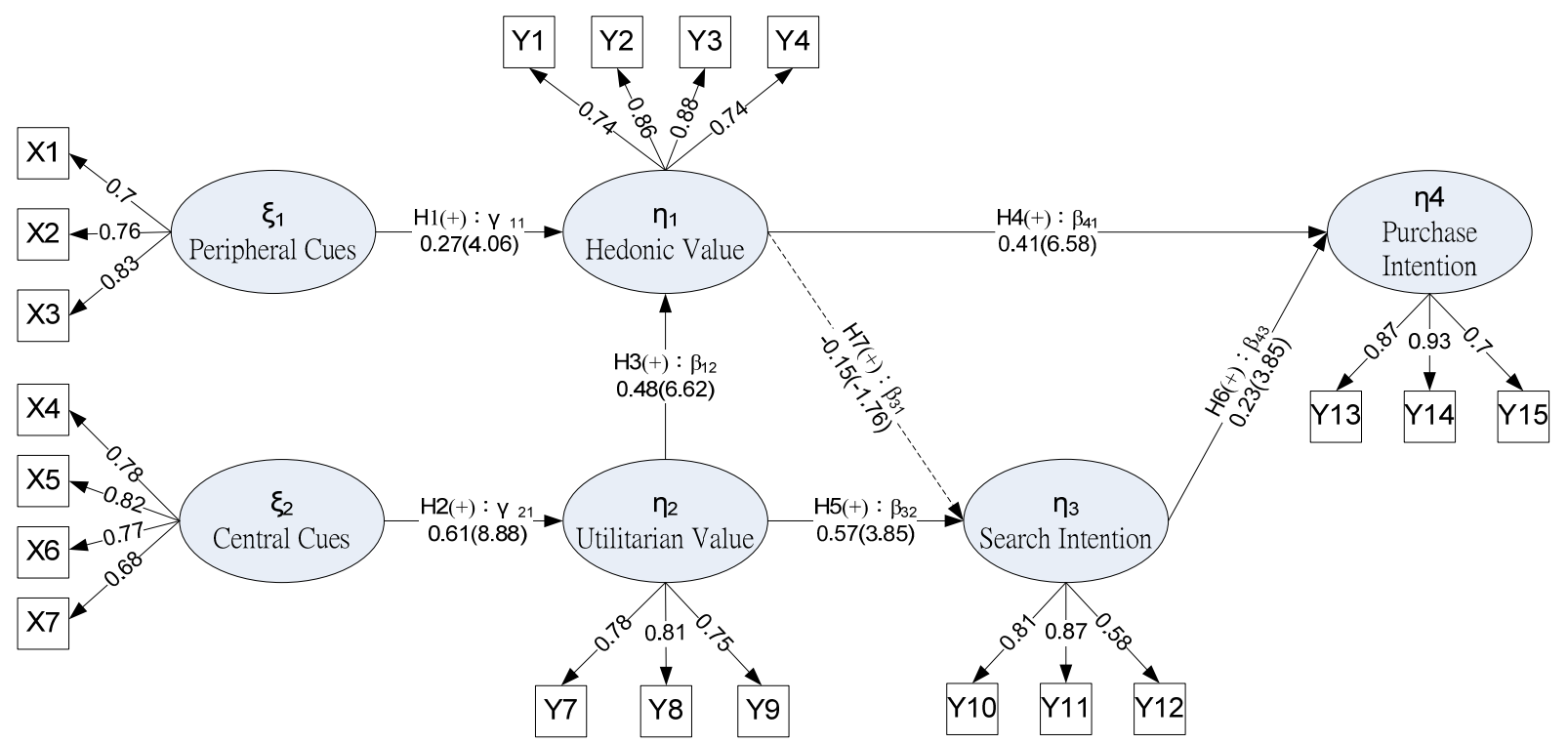

Note: Continuous lines are supported paths and dotted lines, unsupported.

Figure 3. The results of an alterative model $2\left(\mathrm{M}_{\mathrm{A} 2}\right)$

\subsection{The Analysis of Moderating Effects}

The study used multiple-group analysis to investigate the moderating effect of Internet usage on our revised research model $\left(\mathrm{M}_{\mathrm{A} 1}\right)$. The subjects were divided into a high $(\mathrm{n}=143)$ and a low $(\mathrm{n}=169)$ Internet usage group based on their medium hours online per week. Those with more than 28 hours per week were in the former group and all the rest in the latter group.

This $\chi^{2}$ difference test was carried out by constraining appropriate pairs of $\beta$ estimates, one pair at a time, to be equal across the two groups and then evaluating whether the resulting change in the chi-square is significant with one degree of freedom (Bagozzi \& Heatherton, 1994).

Table 6. High and low Internet usage groups: structural parameter estimates, goodness-of-fit indices, and $\chi^{2}$ difference tests

\begin{tabular}{|c|c|c|c|c|c|c|c|}
\hline \multirow{2}{*}{\multicolumn{2}{|c|}{ Paths/Hypotheses }} & \multicolumn{2}{|c|}{ High Internet usage $(\mathrm{n}=143)$} & \multicolumn{2}{|c|}{ Low Internet Usage $(\mathrm{n}=169)$} & \multicolumn{2}{|c|}{$\chi^{2}$ difference test ${ }^{\mathrm{b}}$} \\
\hline & & Estimate $^{\mathrm{a}}$ & $t$-Value & Estimate $^{\mathrm{a}}$ & $t$-Value & $\chi^{2}$ & $\Delta \chi^{2}$ \\
\hline $\mathrm{H} 1$ & $\mathrm{~F} 1 \rightarrow \mathrm{F} 3$ & $\gamma_{11} 0.11$ & 1.11 & $\gamma_{11} 0.37$ & $4.15^{*}$ & --- & $(\mathrm{L}>\mathrm{H})$ \\
\hline $\mathrm{H} 2$ & $\mathrm{~F} 2 \rightarrow \mathrm{F} 4$ & $\gamma, 0.68$ & $7.23 *$ & $\gamma_{n}, 0.55$ & $5.71 *$ & 577.50 & 0.24 \\
\hline $\mathrm{H} 3$ & $\mathrm{~F} 4 \rightarrow \mathrm{F} 3$ & $\beta .0 .67$ & $5.44 *$ & $\beta .0 .39$ & $4.41 *$ & 580.08 & 2.82 \\
\hline $\mathrm{H} 4$ & $\mathrm{~F} 3 \rightarrow \mathrm{F} 5$ & $\beta_{\Lambda} 0.41$ & $4.17^{*}$ & $\beta_{41} 0.39$ & $4.66^{*}$ & 577.28 & 0.02 \\
\hline H5 & $\mathrm{F} 4 \rightarrow \mathrm{F} 5$ & $\beta_{0} 0.52$ & $5.36^{*}$ & $\beta_{2} 0.43$ & $4.47 *$ & 578.64 & 1.38 \\
\hline H6 & $\mathrm{F} 5 \rightarrow \mathrm{F} 6$ & $\begin{array}{l}\beta \\
0\end{array} .27$ & $2.95^{*}$ & $\begin{array}{ll}\beta & 0.19 \\
\end{array}$ & $2.28^{*}$ & 577.36 & 0.10 \\
\hline
\end{tabular}

Goodnessof Fit : $\chi^{2}=577.26 ; \chi^{2} /$ d.f. $=1.7 ; \mathrm{GFI}=0.86 ; \mathrm{AGFI}=0.81$; RMSEA $=0.05 ; \mathrm{NNFI}=0.92 ; \mathrm{CFI}=0.93$

Note. F1, Peripheral cues; F2, Central cues; F3, Hedonic value; F4, Utilitarian value; F5, Search intention; F6, Purchase intention.; ${ }^{a}$ Standardized estimate; ${ }^{\mathrm{b}} \chi^{2}$ difference test (coefficient change is tested by $\chi^{2}$ difference test based on $\Delta \chi^{2}>3.84, \mathrm{p}<0.05$ ); ${ }^{*}$ Significant at $p<$ $0.05(\mathrm{t}>1.96$ or $\mathrm{t}<-1.96)$. 
Table 6 shows the coefficient estimates as well as the goodness-of-fit indices for the two-group comparison. The causal path from peripheral cues to hedonic value in the low-frequency group $\left(\gamma_{11}\right.$, low $\left.=0.37, t=4.15^{*}\right)$ was significant, while the path was not significant in the high-frequency group $\left(\gamma_{11}\right.$, high $\left.=0.11, t=1.11\right)$. Thus, this result shows that peripheral cues exerted a stronger effect on hedonic value in the low Internet usage group than in the high Internet usage group. The $\Delta \chi^{2}$ was lower than 3.84 from the chi-square test on each of the remaining five causal paths, meaning that they all failed to reach statistical significance. Hence, only $\mathrm{H} 7$ was partially supported.

\section{Discussion}

\subsection{Summery of Findings}

This research uses real, current online advertisements as commercial stimuli to explore the routes of persuasion for online advertisements.

$\mathrm{H} 1$ and $\mathrm{H} 2$ are supported, indicating that if consumers perceive that a message contains more contextual information from online advertisements, such as the firm's reputation and attributes not related to the product in question including the friendliness and energy the advertisement conveyed, they tend to produce more affective interpretations of the message, which in turn will lead to a higher level of hedonic cognition. If, however, consumers perceive that the message is more focused on the product itself, such as product information, feature, performance, web link, and sale promotion, then they tend to generate a higher level of utilitarian cognition regarding the advertisement by cognitively elaborating on the core content of the message. The standardized coefficients $\left(\gamma_{21}=0.61>\gamma_{11}=0.27\right)$ of the above-mentioned causal paths indicate that consumers of online retail products are better convinced by advertisements with central cues than by those with peripheral cues.

The second major finding of this study is that utilitarian value positively affects not only search intention but also hedonic value. This finding confirms earlier findings indicating that utilitarian value interacts positively with hedonic value (Babin, Darden, \& Griffen, 1994) and that when online consumers form cognition about an advertisement, this will facilitate more intense hedonic reactions (Hansen, 2005; Fiore \& Kim, 2007). This leads us to conclude that utilitarian value plays an important mediating role, converting rational stimuli into purchase acts.

The third important finding is that although $\mathrm{H} 4$ (which suggested a positive correlation between hedonic value and search intention) is not supported, there is a viable alternative model in which the correlation between hedonic value and purchase intention is not mediated by search intention. This suggests that when online consumers have a more affective response to Internet advertisements, they tend to make purchase decisions that are irrational — they do not engage in product information-gathering but instead make their purchases impulsively.

The fourth major finding is that this study identifies via the most optimal alternative model (see Figure 2) three routes to advertisement persuasion, namely (1) peripheral cues $\rightarrow$ hedonic value $\rightarrow$ purchase intention where the total effect of the peripheral cues on purchase intention is $0.116(0.29 \times 0.40)$, (2) central cues $\rightarrow$ utilitarian value $\rightarrow$ search intention $\rightarrow$ purchase intention, and (3) central cues $\rightarrow$ utilitarian value $\rightarrow$ hedonic value $\rightarrow$ purchase. The total effect of the central cues on purchase intention is 0.18 by adding (2) and (3) together, or $\{(0.61 \times 0.47 \times 0.22)+(0.61 \times 0.47 \times 0.40)\}$. The findings show that central cues of online advertisements produce the better persuasive communication than peripheral cues do.

\subsection{Managerial Implications}

Along the peripheral route (peripheral cues $\rightarrow$ hedonic value $\rightarrow$ purchase intention), consumers focus on the contextual elements of the advertisement, which leads them to have more affective responses to peripheral cues and hence more hedonic experiences. Consumers passively learn the content of the advertisement — bypassing both the gathering of information on the object being advertised and the rational evaluation of the product-and form purchase intention. This process can be viewed as a form of the peripheral processing progression proposed by Petty and Cacioppo (1986). This route applies to persuasive communication about low-involvement products. According to the self-congruity argument (Johar \& Sirgy, 1991), this route to persuasion also can apply to advertisements for hedonic products.

Along the second route (central cues $\rightarrow$ utilitarian value $\rightarrow$ search intention $\rightarrow$ purchase intention), consumers deliberate on and evaluate the content of the core advertising message. This type of consumer tends to assume the cognitive approach and believes that he or she must gather information about the product in question to make the most advantageous purchase decision (Schultz, Martin, \& Brown, 1984). Thus, this route - similar to the central processing route in the ELM - applies to advertisements for high-involvement products. Likewise, this route applies to the persuasive communication regarding utilitarian products (Johar \& Sirgy, 1991).

According to the total effect analysis, the central route to persuasion is still the primary path that consumers use to process persuasive online advertising messages. Consumers tend to deeply consider the online information in 
persuasive messages to form an attitude regarding a product that is persistent, resistant to change, and more predictive of behavior. Furthermore, this experience can encourage emotional modes of persuasion, further increasing purchase intention.

Internet stores are by nature virtual, a characteristic that tends to arouse consumer perception of risks in making a purchase such as the security of electronic payments, product functionality, personal privacy, fraud, and terms of sales (Hsieh \& Tsao, 2013). This leads consumers to view online advertisements more from an utilitarian point of view, paying special attention to in-advertisement, rational descriptions of product attributes, quality, functionality, price, sales promotion, terms of sales, payment methods, and vendor information (Overby \& Lee, 2006). The author suggests that online managers devise their online advertisement appealing primarily to ration. This approach, without regard to product categories, can lead consumers to stronger willingness to purchase.

\subsection{Limitations and Future Research}

This study has a number of limitations. First of all, the advertised products in this study are limited to six categories: clothing, shoes, handbags, cosmetics, weight loss management items, health products, and computer accessories, and thus the results may not apply to all products marketed on the Internet. However, literature indicates that these are the most popular products in online shopping, so the results still have research relevance and practical applicability. Furthermore, restrictions in computer testing limited our means to convenience sampling; the subjects were relatively young, comprising mostly students under 25 years of age. Consequently, the results may not be representative of all online consumers. Relevant investigations have indicated that, college students are an important target audience for many websites. They're young, they spend whatever money they have (often online), and they frequently look for many different types of information (Nielsen, 2010). This shows that students under 25 years of age are active in online shopping. Therefore, despite the limitations to the inferences in this study, they can still reflect the tendencies in the purchase behavior and attitude toward online advertising of the main consumer groups online.

While exploring the process of persuasive communication in Internet advertisements using the ELM model, we did not take consumer involvement into consideration. Different degrees of involvement on the consumer's part can lead to different paths of persuasion (Petty \& Cacioppo, 1986). In addition, the paths of thinking and deliberation in consumers may also vary depending on the type of the product (Johar \& Sirgy, 1991). Therefore, the study suggests that future research consider involvement levels and product types (utilitarian or hedonic) to confirm the managerial implications outlined above.

\section{References}

Anderson, J. C., \& Gerbing, D. W. (1988). Structural equation modeling in practice: A Review and recommended two-step approach. Psychological Bulletin, 103(3), 411-432.

Assael, H. (2005). A Demographic and Psychographic Profile of Heavy Internet Users and Users by Type of Internet Usage. Journal Advertising Research, 45(1), 93-123. http://dx.doi.org/10.1017/S0021849905050014

Babin, B. J., Darden, W. R., \& Griffen, M. (1994). Work and/or fun: measuring hedonic and utilitarian shopping value. Journal of Consumer Research, 20(4), 644-456.

Bagozzi, R. P., \& Heatherton, T. F. (1994). A general approach to representing multifaceted personality constructs: Application to state self-esteem. Structural Equation Modelling, 1(1), 35-67. http://dx.doi.org/10.1080/10705519409539961

Bagozzi, R. P., \& Yi, Y. (1988). On the evaluation for structural equation models. Journal of Academy Marketing Science, 16, 74-94. http://dx.doi.org/10.1177/009207038801600107

Batra, R., \& Ahtola, O. (1990). Measuring the hedonic and utilitarian sources of consumer attitudes. Marketing Letters, 2(2), 159-170. http://dx.doi.org/10.1007/BF00436035

Baumgartner, H., \& Homburg, C. (1996). Applications of structural equation modeling in marketing and consumer research: A review. International Journal of Research in Marketing, 13, 139-161. http://dx.doi.org/10.1016/0167-8116(95)00038-0

Benlter, P. M. (1990). Comparative fit indices in structural models. Psychological Bulletin, 107, 238-246. http://dx.doi.org/10.1037/0033-2909.107.2.238

Blundo, C., Cimato, S., \& De, Bonis. A. (2005). Secure E-Coupons. Electronic Commerce Research, 5(1), 117-139. http://dx.doi.org/10.1023/B:ELEC.0000045976.24984.48 
Bridges, E., \& Florsheim, R. (2008). Hedonic and utilitarian shopping goals: The online experience. Journal Business Research, 61, 309-314. http://dx.doi.org/10.1016/j.jbusres.2007.06.017

Browne, M. W., \& Cudeck, R. (1992). Alternative ways of assessing model fit. In Bollen, K. A., \& Long, J. S. (Eds.), Testing structural equation models. Beverly Hills, CA: Sage. http://dx.doi.org/10.1177/0049124192021002005

Chen, R., \& He, F. (2003). Examination of brand knowledge, perceived risk and consumers intention to adopt an online retailer. Total Quality Management and Business Excellence, 14(6), 677-693. http://dx.doi.org/10.1080/1478336032000053825

Chen, S. H., \& Lee, K. P. (2008). The Role of Personality Traits and Perceived Values in Persuasion: an Elaboration Likelihood Model Perspective on Online Shopping. Social Behavior \& Personality, 36(10), 1379-1400. http://dx.doi.org/10.2224/sbp.2008.36.10.1379

Dodds, W. B., Monroe, K. B., \& Grewal, D. (1991). The Effects of Price, Brand, and Store Information on Buyer's Product Evaluations. Journal of Marketing Research, 28(3), 307-319. http://dx.doi.org/10.2307/3172866

Dohnert. (2013). GroupM Predicts Digital Ad Spend Will Surpass $\$ 113$ Billion in 2013. Retrieved May 10, 2013, from

http://www.clickz.com/clickz/news/2258303/groupm-predicts-digital-ad-spend-will-surpass-usd113-billionin-2013

Eckert, J. A., \& Goldsby, T. J. (1997). Using the elaboration likelihood model to guide customer service- based segmentation. International Journal of Physical Distribution \& Logistics Managerment, 27(9/10), 600-615.

E-Marketer. (2009). Online Ad Spending Slows but Grabs Market Share Read more. Retrieved October 10, 2011, from $\mathrm{http}: / /$ www.eMarketer.com/Article.aspx?R=1007283

Fiore, A. M., \& Kim, J. (2007). An integrative framework capturing experiential and utilitarian shopping experience. International Journal Retail \& Distribution Management, 35(6), 421-442. http://dx.doi.org/10.1108/09590550710750313

Fornell, C. (1992). A National Customer Satisfaction Barometer: The Swedish Experience. Journal of Marketing, 6(1), 6-21. http://dx.doi.org/10.2307/1252129

Fornell, C., \& Larcker, D. (1981) Structural equation models with unobservable variables and measurement error. Journal of Marketing Research, 18(1), 39-50.

Hair, J. F., Anderson, R. E., Tatham, R. L., \& Black, W. C. (1998). Multivariate data analysis. New Jersey, NJ: Prentice-Hall.

Hair, J., Black, W., Babin, B., Anderson, R., \& Tatham, R. (2006). Multivariate Data Analysis (6th ed). New Jersey, NJ: Prentice-Hall.

Hansen, T. (2005). Perspectives on consumer decision making: an integrated approach. Journal of Consumer Behaviour, 4, 420-437. http://dx.doi.org/10.1002/cb.33

Holbrook, M. B. (1978). Beyond Attitude Structure: Toward the Informational Determinants of Attitude. Journal of Marketing Research, 15(4), 545-556. http://dx.doi.org/10.2307/3150624

Hsieh, M. T., \& Tsao, W. C. (2014). Reducing perceived online shopping risk to enhance loyalty: a website quality perspective. Journal of Risk Research, 17, 241-261. http://dx.doi.org/10.1080/13669877.2013.794152

Hu, L., \& Bentler, P. M. (1999). Cut off criteria for fit indexes in covariance structure analysis: conventional criteria versus new alternatives. Structural Equation Modeling, 6(1), 1-55. http://dx.doi.org/10.1080/10705519909540118

Johar, J. S., \& Sirgy, M. (1991). Value-Expressive Versus Utilitarian Advertising Appeals: When and Why to Use Which Appeal. Journal of Advertising, 20, 23-33.

Jöreskog, K. G., \& Sörbom, D. (1992). LISEREL:A guide to the program and application (3rd ed.). Chicago, NY : Scientific Software International Inc.

Keng, C., Liao, T., \& Yang, Y. (2012). The effects of sequential combinations of virtual experience, direct experience, and indirect experience: the moderating roles of need for touch and product involvement. Electronic Commerce Research, 12(2), 177-199. http://dx.doi.org/10.1007/s10660-012-9093-9 
Kotler, P., \& Keller, K. (2008). Marketing Management (13th ed.). New Jersey, NJ: Pearson Education.

Lehdonvirta, V. (2009). Virtual item sales as a revenue model: identifying attributes that drive purchase decisions. Electronic Commerce Research, 9(1/2), 97-113. http://dx.doi.org/10.1007/s10660-009-9028-2

Mathwick, C., Malhotra, B., \& Rigdon, E. (2001). Experiential value: Conceptualization, measurement and application in the catalog and Internet shopping. Journal of Retailing, 77, 39-56. http://dx.doi.org/10.1016/S0022-4359(00)00045-2

Moe, W. W. (2003). Buying, searching or browsing: differentiating between online shoppers using in-store navigational click stream. Journal of Consumer Psychology, 13(1), 29-39. http://dx.doi.org/10.1207/S15327663JCP13-1\&2_03

Morris, J. D., \& Boone, M. A. (1998). The effects of music on emotional response, brand attitude, and purchase intent in an emotional advertising condition. Advances Consumer Research, 25, 518-526.

Morris, J. D., Chong, M. W., \& Singh, A. J. (2005). Elaboration likelihood model: A missing intrinsic emotional implication. Journal of Targeting Measurement and Analysis for Market, 14, 79-98. http://dx.doi.org/10.1057/palgrave.jt.5740171

Morwitz, V. G., \& Schmittlein, D. (1992). Using segmentation to improve sales forecasts based on purchase intent: Which 'intenders' actually buy? Journal of Marketing Research, 29(4), 391-405. http://dx.doi.org/10.2307/3172706

Nakamura, A., \& Abe, N. (2005). Improvements to the Linear Programming Based Scheduling of Web Advertisements. Electronic Commerce Research, $\quad$ 5(1), 75-98. http://dx.doi.org/10.1023/B:ELEC.0000045974.88926.88

Nielsen, J. (2010). College Students (Ages 18-24) on the Web. Nielsen Norman Group press. Retrieved October 15, 2011, from http://www.nngroup.com/articles/college-students-on-the-web/

Nunnally, J. C., \& Bernstein, I. H. (1994). Psychometric theory (3rd ed.). New York, NY: McGraw-Hill.

Overby, J. W., \& Lee, E. (2006). The effects of utilitarian and hedonic online shopping value on consumer preference and intentions. Journal of Business Research, 59, 1160-1166. http://dx.doi.org/10.1016/j.jbusres.2006.03.008

Petty, R. E., \& Cacioppo, J. T. (1984). The effects of involvement on responses to argument quantity and quality: Central and peripheral routes to persuasion. Journal of Personality and Social Psychology, 46, 69-81. $\mathrm{http}: / / \mathrm{dx}$.doi.org/10.1037/0022-3514.46.1.69

Petty, R. E., \& Cacioppo, J. T. (1986). The elaboration likelihood model of persuasion. In L. Berkovitz (Ed.), Advances in experimental social psychology. Orlando, FL: Academic Press.

Petty, R. E., Cacioppo, J. T., \& Goldman, R. (1981). Attitudes and persuasion: Classic and contemporary approaches. Dubuque, IA: WC Brown Co Publishers Iowa.

Salo, J., \& Karjaluoto, H. A. (2007). conceptual model of trust in the online environment. Online Information Review, 31(5), 604-621.

Schultz, D. E., Martin, D., \& Brown, W. P. (1984). Strategic Advertising Campaigns. Chicago, NY: Crain Books Division of Crain Communications Inc.

Simonin, B. L. (1999). Transfer of marketing know-how in international strategic alliances: An empirical investigation of the role and antecedents of knowledge ambiguity. Journal of International Business Studies, 33(3), 463-490.

Solomon, M., Bamossy, G., \& Askegaard, S. (2002). Consumer Behaviour. A European Perspective. New Jersey, NJ: Prentice-Hall.

Sonal, K., \& Preeta, V. (2005). Practices, Perceptions and Avenues of Net-Based Promotions. Electronic Commerce Research, 5(3/4), 401-424. http://dx.doi.org/10.1007/s10660-005-1182-6.

Teo, T. (2001). Demographic and motivation variables associated with Internet usage activities. Internet Research, 11(2), 125-137.

Voss, E. K., Spangenberg, R. E., \& Grohmann, B. (2003). Measuring the hedonic and utilitarian dimensions of consumer attitude. Journal of Marketing Research, 40, 310-320. http://dx.doi.org/10.1509/jmkr.40.3.310.19238 
Wang, S., Beatty, S. E., \& Mothersbaugh, D. L. (2009). Congruity's role in website attitude formation. Journal of Business Research, 62(6), 609-615. http://dx.doi.org/10.1016/j.jbusres.2008.05.020

Wolfinbarger, M., \& Gilly, M. C. (2001). Shopping Online for Freedom, control, and Fun. California Management Review, 43(2), 34-55.

Yoon, S. J., (2002). The antecedents and consequences of trust in online-purchase decisions. Journal of Interactive Marketing, 16(2), 47-63. http://dx.doi.org/10.1002/dir.10008

Zeithaml, V. A. (1988). Consumer Perceptions of Price, Quality, and Value: A Means-End Model and Synthesis of Evidence. Journal of Marketing, 52(3), 2-22.

\section{Copyrights}

Copyright for this article is retained by the author(s), with first publication rights granted to the journal.

This is an open-access article distributed under the terms and conditions of the Creative Commons Attribution license (http://creativecommons.org/licenses/by/3.0/). 